\title{
ENDOPHYTIC BACTERIA FOR BIOLOGICAL CONTROL OF SUGARCANE SMUT DISEASE AND ITS EFFECT ON SOME PLANT GROWTH PARAMETERS
}

\author{
Shadia Taghian ${ }^{1}$, Esh, A.M.H ${ }^{1 *}$, Abdel-Ghaffar, N.Y ${ }^{2}$, and Afaf Z.A. El-Meneisy ${ }^{2}$ \\ 1. Sugar Crops Research Institute, Agricultural Research Centre, Giza, Egypt. \\ 2. Plant Pathology Dept., Fac. of Agric., Ain Shams Univ., P.O. Box 68, Hadyek Shoubra 11241, Cairo, Egypt. \\ *Corresponding author's E-mail: aymanesh@gmail.com
}

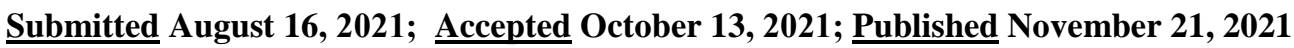

\section{SYMMARY}

In the is study, the endophytic bacteria were isolated from sugarcane stalks and tested for its in vitro antagonistic activity against Sporisorium scitamineum, the causal pathogen of sugarcane smut disease.

Also some physiological characteristics such as its ability to produce some secondary metabolites i.e. PRproteins and growth-promoters were studied in both in vitro and in vivo. Only, 62 isolates among the total 240 isolates were found to have a bioactivity against the pathogen in vitro. Six isolates from the bioactive isolates were selected for its high antagonistic activity to study its potential to produce the enzymes (chitinase, and $\beta$ 1,3 glucanase,) and growth-promoters (indole acetic acid (IAA) as well as siderophores and salicylic acid (SA)) in vitro. The selected isolates showed different degrees of antagonistic activity. The selected isolates were identified using the sequencing of the $16 \mathrm{~S}$ ribosomal RNA (rRna) gene and subjected to mega blast-n in NCBI and proved to be Enterobacter sp.( LUX 27), Kosakonia radicictans (LUX41), Kosakonia radicictans(BAN 33), Klabsiella oxytoca (BAN 39), Bacillus subtilis subsp. Inaquosorum(Q17), Pantoea sp.(SOH 29). In vitro studies proved that, all selected endophytic bacteria produced Nitrogenase and indole acetic acid (IAA) while, Kosakonia radicictans, Klabsiella oxytoca and Bacillus subtilis subsp. Inaquosorum produced salicylic acid. Not one of the selected isolated prove to produce Siderophores. Pantoea sp., Kosakonia radicictans and Klabsiella oxytoca produced chitinase. While, the isolates Kosakonia radicictans and Bacillus subtilis subsp. Inaquosorum were the most effective in producing $\beta$ 1,3glucanase. The bio-control activity of selected isolates was also studied in vivo under greenhouse conditions on sugarcane infected plants. All the tested isolates were completely reduced the disease compared to the infected control. All the selected endophytic bacteria increased Peroxidase, Chitinase and $\beta-1,3$ glucanaseactivities in the treated plants while the isolates Kosakonia radicictans and Enterobacter sp. didn't produce Polyphenol-oxidase in treated infected plants. The treated sugarcane plants showed a range of positive increase in Leaf Area, Stalk length, Stalk Diameter, number of tillers and total chlorophyll compared to the untreated healthy and infected control. The present study show the efficiency of using endophytic bacteria as a bio-control system against sugarcane smut.

Keywords: Endophytic bacteria, Antagonistic effect, Chitinase, $\beta$ 1, 3glucanase, Siderophores, Indole acetic acid (IAA) and Salicylic acid (SA).

\section{INTRODUCTION}

Sugarcane considered as an important industrial crop. It is covering 62 million hectares in more than 100 countries. Sugarcane is a tropical and sub tropical plant, can be produced in different climates range from hot dry to cool and humid environment at higher elevations (Mehnaz, 2009).

Sugarcane smut disease caused by, Sporisorium scitamineum (syd.)Piepenbring et al., 2002 formally named (Ustilago scitaminea). The fungus belongs to Phylum: Basidiomycota; Class: Ustilaginomycetes. In Egypt the disease was reported for the first time in 1935 (Jones et al., 1935). The only control procedures of the disease is using resistant varieties or the hot water treatment of the seed - cane( cutting) before cultivation. Chemical control of the disease is very difficult and high cost in its application. The use of biological control of the disease is essential as the plant reproduce vegetatively.
The plants and microorganisms relation is complicated and affected by the environmental conditions and microorganisms that affected by nutrition and plant physiological condition (Shastri et al., 2020). Endophytic bacteria reported as group of rhizospheric bacteria, named plant growth promoting rhizobacteria (PGPR). It is a specific group of rhizobacteria that can live symbiotically inside the host plants (Reinhold-Hurek and Hurek, 1998).

In sugarcane, most of the research on endophytic bacteria has been focused on nitrogen fixing bacteria. Only few studies has been conducted on the sugarcane disease control by using endophytic bacteria. Liu et al., (2017) reported a mechanism of endophytic bacteria to control $\mathrm{S}$. scitamineum in sugarcane. Viswanathan et al., (2003) reported Pseudomonas aeruginosa, Pseudomonas fluorescens and Pseudomonas putida as endophytic bio-control bacteria against sugarcane red rot pathogen. 
Therefore, it is necessary to find a new endophyte sand explore their role in enhancing plant growth and plant disease control. Thus, the aim of this study was to isolate and characterize endophytic bacteria that are related to sugarcane and test its ability to act as a bio-control agent against sugarcane smut pathogen besides enhancing plant growth.

\section{MATERIALS AND METHODS}

\section{1- Collection and isolation of sugarcane smut} causal organism in the main growing areas:

\section{1- Collection of sugarcane smut spores:}

Samples of sugarcane smut whips were collected from commercial varieties cultivated in sugarcane main growing areas in Upper Egypt. Collected whips separated and left on laboratory bench under room temperature for 5 days. After dryness, the whips crashed by hand in a big container to release the spores.

The major plant depresses removed and the remains were screened through a fine mesh to collect the spores. The activity of the collected spores was evaluated by in vitro germination method described by (Comstock and Heinz 1977) to assure the percentage of spore germination is above $80 \%$. The collected spores were stored in a paper bags in the freezers at $-40^{\circ} \mathrm{C}$.

\section{3-Pathogenicity test:}

The pathogenicity test was conducted to the isolates in vivo. Spore suspension $10^{4} / \mathrm{ml}$ of each isolate was prepared using distilled water then 10 sugarcane one bud cuttings were socked in each suspension for one hour and then transferred to the greenhouse for cultivation in $30 \mathrm{~cm}$ diameter pots.

The disease incidence was checked after 3 months from inoculation and the percentage of diseased plants were calculated.

The S. scitamineum isolate that proved the highest virulence was selected to present the pathogen in the entire work.

\section{Isolation and purification of endophytic bacteria from sugarcane plants:}

Sugarcane stalk samples (160 samples) were collected from five governorates (El-Giza, BeniSuef, Sohag, Qeina and Luxor) during growing seasons 2018-2019. Collected samples were washed in running water. Hundred gram from each sample were disinfected superficially according to Araujo et al. (2001) and Queiroz et al. (2012). Through the following protocol :70\% alcohol for $1 \mathrm{~min}$, sodium hypochlorite $(2.5 \%)$ for $4 \mathrm{~min}$, ethanol for 30 second and 3 rinses in sterile distilled water.

The samples were ground with $90 \mathrm{ml}$ of aqueous solution $(0.9 \% \mathrm{NaCl})$ using a sterile mortar and pestle. The tissue extract was subsequently incubation at $28^{\circ} \mathrm{C}$ for 3 hours to allow the complete release of endophytic bacteria from the host tissue.

The tissue extract was diluted $\left(10^{-1}\right.$ and $\left.10^{-2}\right)$ in aqueous solution $(0.9 \% \mathrm{Nacl})$.
Five-hundred micro-litter/ dilution was cultivated on plates containing LGI medium Hartmannand Baldani (2006) - $\left(\mathrm{K}_{2} \mathrm{HPO}_{4} \quad 0.2 \mathrm{~g}, \mathrm{KH}_{2} \mathrm{PO}_{4} \quad 0.6 \mathrm{~g}\right.$, $\mathrm{MgSo}_{4} 7 \mathrm{H}_{2} \mathrm{O} \quad 0.2 \mathrm{~g}, \quad \mathrm{Na}_{2} \mathrm{MoO}_{4} 2 \mathrm{H}_{2} \mathrm{O} \quad 0.002 \mathrm{~g}$, $\mathrm{CaCl}_{2} 2 \mathrm{H}_{2} \mathrm{O} 0.02 \mathrm{~g}$, Sucrose $100 \mathrm{~g}$, Bromothymolblue $5 \mathrm{ml}, \mathrm{pH}=5.5-6$ ) - and spread using sterilized Lshaped glass rod. Inoculated plates were incubated for up to 15 days at $30 \pm 2^{\circ} \mathrm{C}$. Different types of bacterial colonies were selected on days 5, 10 and 15 days of incubation depending on the morphological characteristic (color, size and shape) and their time of growth.

Selected bacteria were picked up and streaked on petri-dishes containing an appropriate medium for purification.

The purified bacterial isolates were transferred to slants of YGC medium (yeast extract $5 \mathrm{~g}$; glucose $15 \mathrm{~g}$ and $0.1 \%$ calcium carbonate) amend with / without $0.5 \mathrm{~g} / 1$ active charcoal and incubated at 30 ${ }^{\circ} \mathrm{C}$ for $48-72$ h.) and kept at $4{ }^{\circ} \mathrm{C}$ for further investigation or in $20 \%$ sterilized glycerol at $-80^{\circ} \mathrm{C}$ for long preservation.

\section{Antagonistic effect of the different isolated endophytic bacteria on Sporisorium scitamineum growth in vitro:}

In this study Conventional streak was used to determine the antagonistic relation between the tested bacterial isolates and the pathogen Sporisorium scitamineum.

Interactions between antagonistic bacteria and pathogenic fungus were determined by the Conventional streak described by (Kucuk and Kyvanc, 2003). Mycelia disks (5 $\mathrm{mm}$ in diameter) of Sporisorium scitamineum isolate were placed on center of a Petri dish containing PDA medium, while the bacterial isolates were streaked the two side of the plate. After the desired incubation time (20 days), at $28 \pm 2{ }^{\circ} \mathrm{C}$, the growth reduction in Sporisorium scitamineum colony was determined and compared to control experiment where the bacterial was replaced by desk media.

The plates incubated at $28 \pm 2{ }^{\circ} \mathrm{C}$ for 20 days under weekly observations. At the end of incubation period, the average of longest and shortest diameter of Sporisorium colony was measured in the treated plates.

The antagonistic potential of the bio-agents expressed according to the following formula: Antagonistic potential $(\%)=[(\mathrm{C}-\mathrm{T}) \backslash \mathrm{C}] \mathrm{X} 100$ Where:

$\mathrm{C}=$ diameter of radial growth of the pathogenic fungus on plates containing it only.

$\mathrm{T}=$ diameter of radial growth of the pathogenic fungus on plates paired with each antagonistic bacteria (dual cultures).

\section{Physiological characteristics of the isolated endophytic: \\ 4.1. Determination of Indol acetic acid (IAA):}

To determine the ability of the tested endophytic bacteria to produce IAA, a colorimetric technique 
was performed using the Van Urk Salkowski reagent $\left(1 \mathrm{ml}\right.$ of $0.5 \mathrm{M} \mathrm{FeCl}_{3}$ and $50 \mathrm{ml}$ of $35 \% \mathrm{HClO}_{4}$ in water); the microorganisms were grown in nutrient broth containing $0.2 \%$ L-tryptophan and incubated at a $35^{\circ} \mathrm{C}$ of temperature for 5 days.

Cultures were centrifuged $(1000 \mathrm{rpm})$ after the incubation time then $1 \mathrm{ml}$ of the supernatant mixed with $2 \mathrm{ml}$ of the reagent and incubated for $25 \mathrm{~min}$. at room temperature.

The optical density was measured using the wavelength $530 \mathrm{~nm}$. A standard curve of pure IAA (Sigma-Aldrich) was used as standard to calculated IAA production from tested isolates (Bricet et al., 1991).

\subsection{Determination of Siderophores:}

The tested endophytic bacterial isolates were grown in King's B broth (King et al 1948) for 5 days at $35 \pm 2^{\circ} \mathrm{C}$ and centrifuged at $10000 \mathrm{rpm}$ for $10 \mathrm{~min}$. The $\mathrm{pH}$ of the supernatant was adjusted to 2.0 with diluted $\mathrm{HCl}$ and equal quantity of ethyl acetate was added in a separating funnel, mixed well and ethyl acetate fraction was collected.

The determination of Siderophores was done according to the method described by Reeves et al., 1983.

\subsection{Determination of Salicylic acid (SA):}

The ten selected endophytic bacterial isolates were grown at $35 \pm 2{ }^{\circ} \mathrm{C}$ for 5 days on a rotary shaker incubator in $250 \mathrm{ml}$ conical flasks containing $50 \mathrm{ml}$ of succinate medium.

The quantity of SA in the culture filtrate was determined according to the method described by Meyer et al., 1992 and expressed as $\mathrm{mg} / \mathrm{ml}$.

\subsection{Determination of Chitinase:}

Bacterial isolates were grown in $250 \mathrm{ml}$ conical flasks containing $50 \mathrm{ml}$ of chitin-peptone medium for bacterial isolates according to Berger and Reynolds, (1958).

The bacterial cultures were incubated at $35^{\circ} \mathrm{C}$ for 5 days. After the incubation period, the cultures were centrifuged and the supernatant was used as crude enzyme source.

The Chitinase activity was determined according to Reissig et al., (1955) as the release of $\mathrm{N}$ acetylglucosamine in the reaction mixture. The activity was expressed as $\mu \mathrm{g}$ of glucose released / $\mathrm{ml}$ $/ \mathrm{min}$

\subsection{Determination of $\beta 1,3$ glucanase:}

Bacterial isolates were grown in $250 \mathrm{ml}$ conical flasks containing $50 \mathrm{ml}$ of peptone medium contained laminarin $(0.2 \%)$ (From Laminariadigitate SigmaAldrich) and incubated at $35^{\circ} \mathrm{Cfor} 5$ days on a rotary shaker incubator according to Lim et al., (1991).

The reaction mixture, the substrate laminarin $(2.5 \% \mathrm{w} / \mathrm{v})$ in $10 \mathrm{mM}$ ammonium acetate, $\mathrm{pH}$ 6.0, and $1 \mathrm{mM}$ DTT. Samples were assayed for the release of reducing sugars according to the Somogyi-Nelson method Naguib, (1965). $\beta$ 1,3 glucanase activity was determined as $\mu \mathrm{g}$ of glucose released $/ \mathrm{ml} / \mathrm{min}$.

\subsection{Determination of nitrogenase activity:}

The nitrogenase activity of the selected endophytic bacteria isolated were conducted using acetylene reduction technique according to Dilowrth, 1966 in Soil Microbiology Department, Soil and Water research institute, Agricultural Research Center, Giza, Egypt. Results were calculated as ethylene produced/ml liquid culture / hr.

\section{Greenhouse trials:}

5.1. Effect of the selected different isolates of endophytic bacteria on sugarcane smut disease incidence in vivo:

\subsubsection{Inoculum preparation of the selected endophytic bacteria organisms:}

Bacterial isolates were grown in $250 \mathrm{ml}$ nutrient broth at $35 \pm 2^{\circ} \mathrm{C}$ for 5 days on a rotary shaker. After the end of incubation period the bacterial suspensions diluted by sterilized distilled water up to $1000 \mathrm{ml}$ to be ready to socking by the endophytic bacteria for one hour before culture.

Sugarcane one bud sets of variety GT54-9 were socked in the tested endophytic bacteria suspension for one hour before culture. Sugarcane plants were grown in $30 \mathrm{~cm}$ diameter pots filled with $3 \mathrm{~kg}$ (sand: peat moss: clay soil) $(1: 1: 1)$.

\subsubsection{Inoculation of the endophytic bacteria pre- infested sugarcane plants with the pathogen:}

The hypodermic injection technique according to (Gillaspie et al., 1983) was used to inoculate the emerged plants. Shoots were inoculated when they were $20 \mathrm{~cm}$ long (4-5 weeks old).

The teliospores suspensions contained about $5 \times 10^{5}$ viable spores per milliliter of distilled water.

To reduce surface tension, Tween 20 was added at a rate of $100 \mathrm{ul}$ per $100 \mathrm{ml}$ of spore suspension. The spore suspension was injected twice into each plant at the base of the shoot $(0.1 \mathrm{ml}$ per injection) around the meristemic region, or until the inoculum was forced out the shoot tip.

The numbers of infected plants showing the typical symptoms of smut (whip formation) were recorded weekly for each treatment during the time of experiment.

6. Effect of the selected different endophytic bacteria isolates on the characteristics of sugarcane infested and un-infested plant:

After 4 months, the bacteria treated infected and treated un infected plants, plant height $(\mathrm{cm})$; stalk diameter $(\mathrm{cm})$; and leaf area (average of leaves area $\left.\mathrm{cm}^{2} \mathrm{~F} 1\right)$ and total chlorophyll were determined.

6.1. Effect of bio-agent application on some Pathogenesis related proteins (PR) and growth factors in both infected and un-infected sugarcane plants: 


\subsubsection{Preparation of samples:}

Leaf samples were collected from treated sugarcane plants variety (GT54-9) after one week from pathogen inoculation. Samples were frozen in liquid nitrogen $\left(\mathrm{L}-\mathrm{N}_{2}\right)$ then grounded in a mortar and pestle to form a fine powder.

One gram of the grounded tissues was mixed with $2 \mathrm{ml}$ of extraction buffer according to Bollag et al., (1996). Samples were vortexed and centrifuged at $13000 \mathrm{rpm}$ for $15 \mathrm{~min}$. under $4^{\circ} \mathrm{C}$ to remove cell debris. The clear supernatant (crude enzyme source) was collected and kept at $-80^{\circ} \mathrm{C}$ for further study (Soltis and Pamela Soltis, 1990).

\subsubsection{Determination of peroxidase $(P O)$ :}

The reaction mixture extraction as described by Malik and Singh, (1990) was contained $0.5 \mathrm{ml}$

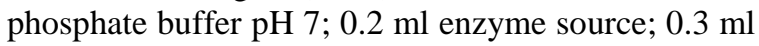
of $0.05 \mathrm{M}$ pyrogallol; $0.1 \mathrm{ml}$ of $1 \%(\mathrm{v} / \mathrm{v}) \mathrm{H}_{2} \mathrm{O}_{2}$ and distilled water was added up to obtained $3 \mathrm{ml}$.

The reaction mixture was incubated at $30{ }^{\circ} \mathrm{C}$ for 5 min. then the reaction stopped by adding $0.5 \mathrm{ml}$ of 5 $\%(\mathrm{v} / \mathrm{v}) \mathrm{H}_{2} \mathrm{O}_{2}$ (Kar and Mishra, 1976).

One unit of peroxidase activity was expressed as the changes in absorbance at $425 \mathrm{~nm} / \mathrm{min}$. / $1 \mathrm{~g}$ fresh weight.

\subsubsection{Determination of Polyphenoloxidase (PPO):}

Samples were extracted according to the method described by Malik and Singh, (1990).

The enzyme extract was prepared by grounding 5 $\mathrm{g}$ leaves in $0.1 \mathrm{M}$ sodium phosphate buffer $\mathrm{pH} 7$ (2 $\mathrm{ml} / \mathrm{g}$ fresh weight), then centrifuged at $6000 \mathrm{rpm}$ for 30 min. under $4{ }^{\circ} \mathrm{C}$, the clear extract was collected, completed to $15 \mathrm{ml}$ volume using phosphate buffer and used as crude enzyme source.

The reaction mixture contained $0.2 \mathrm{ml}$ of crude enzyme source, $1 \mathrm{ml}$ of phosphate buffer $\mathrm{pH} \mathrm{7;1 \textrm {ml }}$ of $10^{-3} \mathrm{M}$ catechol and complete with distilled water up to $6 \mathrm{ml}$.

The reaction was incubated for $30 \mathrm{~min}$. at $30{ }^{\circ} \mathrm{C}$. One unite of polyphenoloxidase was expressed as the change in absorbance at $420 \mathrm{~nm} / 30 \mathrm{~min}$. / $1 \mathrm{~g}$ fresh weight.

\subsubsection{Chitinase and $\beta-1,3$ glucanase:}

Chitinase activity and $\beta-1,3$ glucanase activity was determined according to the method mentioned in 4.4 and 4.5.

\section{Identification of the selected active endophytic bacteria using $16 \mathrm{~S}$ rRNA gene methods:}

The selected endophytic bacteria isolates were cultured in Nutrient broth and incubated at $28^{\circ} \mathrm{C}$ for $24 \mathrm{~h}$ then centrifuged at 14,000 r.p.m. for $5 \mathrm{~min}$ at $4^{\circ} \mathrm{C}$.

The genomic DNA was extracted from the pellet by using bacterial genomic DNA extraction kit (Bioflux cat.no. BSC03S1).
The isolated DNA were kept in $-40^{\circ} \mathrm{C}$. The $16 \mathrm{~S}$ rRNA genes, the polymerase chain reaction (PCR) was performed with the universal primers $27 \mathrm{~F} 5^{\prime}$ AGAGTTTGATCMTGGCTC AG-3' and 1492R 5'TACGGYTACCTTGTTACGACTT 3' (Weisburg et al., 1991). The PCR consisted of a $95^{\circ} \mathrm{C}$ hold for 5 min, followed by 35 cycles of $45 \mathrm{sec}$ at $95^{\circ} \mathrm{C}, 30 \mathrm{sec}$ at $55^{\circ} \mathrm{C}, 30 \mathrm{sec}$ at $72^{\circ} \mathrm{C}$, and a final extension for 15 min at $72^{\circ} \mathrm{C}$. The amplification was performed using a PCT-100 thermal cycler.

The PCR fragment was purified by using a PCR Purification kit (QIAGEN, USA).The PCR products of the selected endophytic bacteria Isolates were purified using Wizard $®$ DNA Clean-Up System (Promega).

DNA of each sample were sent for direct sequencing using $\mathrm{ABI} 3730 \mathrm{XL}$ sequencers at MACLAB, 384 Oyster Point Boulevard, Suite 15 South San Francisco, CA 94080, U.S.A. http://www.mclab.com/home.php). For each isolate, forward and reverse sequences were assembled and edited using the program DNAMAN V5.2.2 (Lynnon bio Soft). The obtained sequences were then compared to the National Center for Biotechnology Information (NCBI) database for BLASTn analysis according to Morgulis et al., (2008).

\section{RESULTS}

\section{1-Collection of sugarcane smut causal organism:}

Results showed that 54 infected samples of sugarcane plants were collected from five different governorates. The isolation efficiency was $100 \%$ from all the samples.

A total 54 fungus isolate were isolated from collected 54 samples during growing seasons 2019.

\section{2- Antagonistic effect of the different isolated endophytic bacteria on Sporisoriumscitamineum growth in vitro \\ Two hundred and ten bacterial isolates were} isolated from the collected 160 samples among of them 6 isolates proved positive antagonistic activity.

The data show in Fig. 1 and Table (1) the number of sample, the total isolated bacteria and the number isolates showed antagonistic activity against the pathogen. Six bacterial isolates showed the highest antagonistic activity in vitro against $\mathrm{S}$. scitamineum.

It is worthy to mention that, the origin of the majority of the selected bacterial isolates were from samples collected from Luxor government (2 isolates) followed by Qena government (1 isolate), Beni-Suef and Sohag governments (2, 1 isolates respectively).

The isolates of BAN33, Q17 and SO29 showed the significant highest percentage of growth reduction $(54.7,44.7$ and $39.9 \%$ respectively). On the other hand, isolates of, LUX 41, LUX 27 and BAN39 significantly reduced the liner growth of $\mathrm{S}$. scitamineum by $(25.7,23.5$ and $11.5 \%$ respectively) 


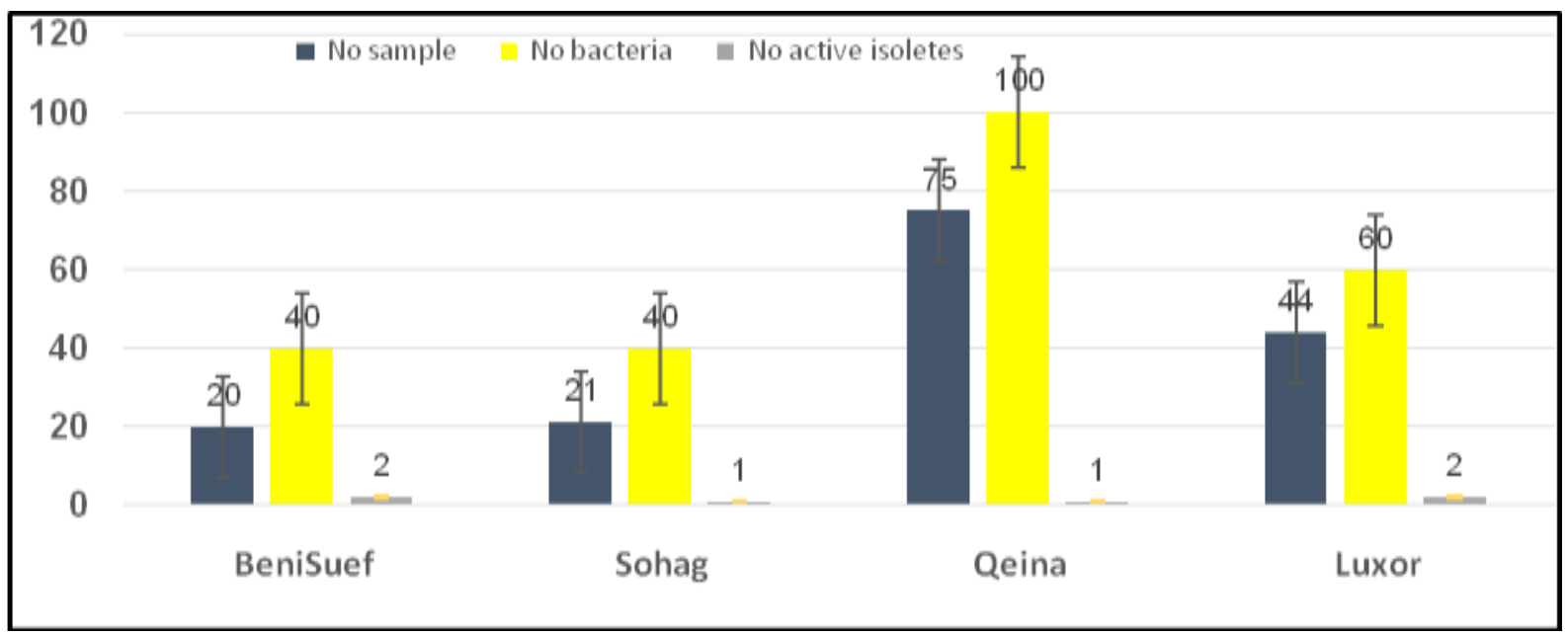

(Fig 1): Isolation of endophytic bacteria collected from different localities in five governorates in Upper Egypt, during the growing seasons 2019-2020

Table (1): Antagonistic effect of selected sugarcane entophytic bacterial isolates on the growth of $S$. scitamineum, on PDA medium using dual culture assay

\begin{tabular}{ccc}
\hline No. & Isolate code & Linier growth reduction compared to pathogen control (\%) \\
\hline 1 & SOH 29 & 39.9 \\
2 & LUX 27 & 23.5 \\
3 & LUX41 & 25.7 \\
4 & BAN 33 & 54.7 \\
5 & BAN 39 & 11.5 \\
6 & Q17 & 44.4 \\
7 & LSD at 5\% & 8.4 \\
\hline
\end{tabular}

\section{3-Physiological characteristics of the isolated endophytes:}

The ability of the selected bacterial to produce indole acetic acid was determined as shown in Table (2). It is noticed that, the ability of the selected biocontrol active bacterial isolates significantly differed.

Isolate of LUX 27 showed the highest significant ability in producing IAA $(1.7(\mu \mathrm{g} / \mathrm{ml}))$ followed by BAN 33 isolates $(0.99 \mu \mathrm{g} / \mathrm{ml})$.

While the isolates of LU41 and BAN39 recorded the lowest significant IAA production among all the tested bacterial isolates $(0.4$ and $0.1 \mu \mathrm{g} / \mathrm{ml})$.

While the isolates of $\mathrm{SOH} 29$ and Q17 gave the same result $0.3 \mu \mathrm{g} / \mathrm{ml}$. On the other hand, none of the selected bacterial isolates were able to produce siderophores in the medium the same was with SA production except two isolates BAN 33 and BAN 39 that were able to produce SA 0.3 and $0.4 \mathrm{mg} / \mathrm{ml}$, respectively).

The obtained data also showed that, the highest significant nitrogenase activity recorded by $\mathrm{SOH} 29$ and BAN 39 isolates (1.34nmole/C2H4/ml/hr) followed LUX27 and Q17 isolates which recorded (1.1 nmole/C2H4/ml/hr., respectively), BAN 33 isolate gave $(0.9 \mathrm{nmole} / \mathrm{C} 2 \mathrm{H} 4 / \mathrm{ml} / \mathrm{hr}$.$) and$ LUX41(0.4 nmole/C2H4/ml/hr).

Table (2): Estimation of indole acetic acid (IAA), salicylic acid (SA), siderophores and nitrogenase activity content (Optical Density at $700 \mathrm{~nm}$ ) produced by different endophytic bacteria, In vitro

\begin{tabular}{lcccc}
\hline Isolate & IAA $(\boldsymbol{\mu g} / \mathbf{m l})$ & Siderophores & $\mathbf{S A ~} \mathbf{~ m g} / \mathbf{m l}$ & $\begin{array}{c}\text { Nitrogenase } \\
\left(\mathbf{n m o l e} / \mathbf{C}_{\mathbf{2}} \mathbf{H}_{\mathbf{4}} / \mathbf{m l} / \mathbf{h r}\right)\end{array}$ \\
\hline SOH 29 & & & & 1.34 \\
LUX 27 & 0.3 & 0 & 0 & 1.1 \\
LUX41 & 1.7 & 0 & 0 & 0.40 \\
BAN 33 & 0.4 & 0 & 0.3 & 0.9 \\
BAN 39 & 0.99 & 0 & 0.4 & 1.34 \\
O17 & 0.1 & 0 & 0.0 & 1.1 \\
LSD at 5 $\%$ & 0.3 & 0 & - & 2.7 \\
\hline
\end{tabular}

On the other hand, concerning the ability of the tested isolates to produce the hydrolytic enzymes chitinase and $\beta-1,3$ glucanase in vitro the data presented in
Table, (3) show that three isolates BAN39, SOH 29 and LUX 41 showed chitinase activity among the tested isolates $(8.05,1.81$ and 1.3 ug of glucose 
released $/ \mathrm{ml} / \mathrm{min}$, respectively) while the majority of the tested bacterial isolates were not able to produce $\beta-1,3$ glucanase, in vitro. The isolates (BAN 33 and,
Q17 recorded $\beta-1,3$ glucanaseactivity (3.1, and $1 \mathrm{~g}$ of glucose released $/ \mathrm{ml} / 15 \mathrm{~min}$, respectively).

Table (3): Activity of chitinase and $\beta$-1, 3-glucanase enzymes of different endophytic bacteria

\begin{tabular}{|c|c|c|}
\hline \multirow{2}{*}{ Isolate } & Chitinase & B-1,3 glucanase \\
\hline & \multicolumn{2}{|c|}{ Enzyme activity as $\mu \mathrm{g}$ of glucose released / $\mathrm{ml} / \mathrm{min}$. } \\
\hline SOH 29 & 1.81 & 0 \\
\hline LUX 27 & 0 & 0 \\
\hline LUX41 & 1. 31 & 0 \\
\hline BAN 33 & 0 & 3. 108 \\
\hline BAN 39 & 8.05 & 0 \\
\hline Q17 & 0 & 1 \\
\hline LSD at $5 \%$ & 1.98 & 1.21 \\
\hline
\end{tabular}

6. Greenhouse trials:

6.1. Effect of the selected different isolates of endophytic bacteria on sugarcane smut disease incidence, in vivo under greenhouse conditions:

The present experiment was carried out to evaluate the bio-control activity of the selected bacterial isolates as biological control agents against the disease under greenhouse condition.

All the tested endophytic bacteria isolates were able to $100 \%$ inhibit the disease incidence in infected plants compared to the un-treated infected control plants.

7. Effect of the selected different isolates of endophytic bacteria on sugarcane plant characteristics (Leaf area, Stalk length, Stalk diameter, Number of tillers and total chlorophyll:

In this experiment, the effect of the endophytic bacteria on treated uninfected and treated infected sugarcane plants on some plant characteristics were measured and tabulated in table 4.

Data in Table (4) show the effect of endophytic bacteria treatment on the leaf area of sugarcane treated plants.

The endophytic bacteria isolate $\mathrm{SOH} 29$, recorded the highest significant leaf area $\left(220 \mathrm{~cm}^{2}\right)$ followed by the Isolates BAN33, LUX41, LUX27, Q17and BAN39 (170, 120, 100, 95 and 50 respectively.). On the other hand, the recorded leaf areas resulted from the the treated un-infected plants increased the leaf area significantly compared with the healthy untreated control.

The obtained data showed that, the highest significant increase in leaf area was recorded by the isolate $\mathrm{SOH} 29\left(225 \mathrm{~cm}^{2}\right)$ followed by the isolates (BAN 33 and LUX 41) which recorded a significant increase in leaf area $\left(180\right.$ and $\left.120 \mathrm{~cm}^{2}\right)$.

The isolates Q17, LUX27 and BAN39 recorded the same leaf area $\left(100 \mathrm{~cm}^{2}\right)$.
The effect of the treatments of different endophytic bacteria either with or without the existence of the pathogenic fungus on sugarcane stalk length has been studied. Data in table (4)show that, the isolates (BAN33, SOH29, LUX41 and BAN39) which recorded stalk length ranged from 65 to 125 $\mathrm{cm}$ in the infected treated plants compared with the infected un treated and the healthy treated control witch recorded $43 \mathrm{~cm}$ and $70 \mathrm{~cm}$ respectively.

The diameters of sugarcane stalk were significantly increased in treated infected and treated on infected plants (Table, 4).

The isolates SOH29, BAN33 and BAN39 showed a significant increase in the stalk diameter $(2.3,2.1$ and $1.5 \mathrm{~cm}$ respectively) compared to the healthy untreated control $(1.2 \mathrm{~cm})$. Only two isolates Q17 and LUX27 that didn't show any significant difference with the treated infected control.

Concerning the effect of the application of endophytic bacteria in infected and healthy sugarcane plants.

The presented data in Table 4 show that the isolates Q17, LUX 27, LUX 41, SOH29, BAN33 and BAN 39 significantly increased the resulted tillers which ranged from 2-8 tillers from the main plant compared with the treated infected control (1.83 tillers).

The application of pathogenic fungus and endophytic bacteria affected on total chlorophyll in sugarcane plants compared with control treatment. The application with the endophytic bacterial isolates BAN33, Q17, BAN39, LUX41 and SOH29 led to a significant increase in the total chlorophyll in the infected sugarcane plants the increase ranged from 37.3 to $47 \mathrm{ug} / \mathrm{gram}$ fresh weight compared with the infected untreated control (26.8. ug/gram fresh weight).

It worthy to mention that, isolate LUX 27 didn't show any significant increase in the total chlorophyll. 
Table (4) Effect of the selected endophytic bacteria on Leaf Area, Stalk length, Stalk Diameter, number of tillers and total chlorophyll sugarcane plants treated with the selected endophytic bacteria

\begin{tabular}{|c|c|c|c|c|c|c|c|c|c|c|}
\hline \multirow[t]{2}{*}{ Isolate code } & \multicolumn{2}{|c|}{$\begin{array}{c}\text { Leaf area } \\
\left(\mathrm{cm}^{2}\right)\end{array}$} & \multicolumn{2}{|c|}{$\begin{array}{l}\text { stalk length } \\
(\mathrm{cm})\end{array}$} & \multicolumn{2}{|c|}{$\begin{array}{c}\text { Stalk } \\
\text { diameter }\end{array}$} & \multicolumn{2}{|c|}{$\begin{array}{c}\text { Tillers } \\
\text { number }\end{array}$} & \multicolumn{2}{|c|}{$\begin{array}{l}\text { Total Chlorophyll } \\
\text { (microgram/gram } \\
\text { fresh weight) }\end{array}$} \\
\hline & $\mathbf{F}+\mathbf{B}$ & B & $\mathbf{F}+\mathbf{B}$ & $\underline{\mathbf{B}}$ & $\mathbf{F}+\mathbf{B}$ & B & $\mathbf{F}+\mathbf{B}$ & $\underline{\mathbf{B}}$ & $\mathbf{F}+\mathbf{B}$ & $\underline{\mathbf{B}}$ \\
\hline Q17 & 95 & $\overline{100}$ & 72 & $\overline{70}$ & $\overline{0.9}$ & $\overline{1.3}$ & 8 & $\overline{8}$ & $\overline{42.5}$ & $4 \overline{0.1}$ \\
\hline LUX27 & 100 & 100 & 65 & 70 & 1.3 & 1.3 & 2.17 & 6.33 & 30 & 43 \\
\hline LUX41 & 120 & 120 & 90 & 89 & 1.4 & 1.3 & 1 & 4 & 40.3 & 39.6 \\
\hline $\mathrm{SOH} 29$ & 220 & 225 & 110 & 120 & 2.1 & 2.3 & 3 & 1 & 39.6 & 40.8 \\
\hline BAN33 & 170 & 180 & 125 & 122 & 2 & 2.1 & 2 & 3.83 & 44.8 & 40.6 \\
\hline BAN39 & 50 & 100 & 45 & 70 & 1.3 & 1.5 & 8 & 5 & 41.5 & 39.9 \\
\hline Infected & \multicolumn{2}{|c|}{40.0} & \multicolumn{2}{|c|}{43.0} & \multicolumn{2}{|c|}{0.5} & \multicolumn{2}{|c|}{1.83} & \multicolumn{2}{|c|}{26.8} \\
\hline Healthy & \multicolumn{2}{|c|}{100} & \multicolumn{2}{|c|}{70} & \multicolumn{2}{|c|}{1.2} & \multicolumn{2}{|c|}{1.66} & \multicolumn{2}{|c|}{35.3} \\
\hline LSD at $5 \%$ & 13.6 & 14.1 & 8.3 & 9.2 & 0.6 & 0.5 & 2.8 & 2.3 & & \\
\hline
\end{tabular}

$\mathrm{F}+\mathrm{B}=$ Plants treated with the endophytic bacteria and inoculated with the pathogenic fungus. $\mathrm{B}=\mathrm{Plants}$ treated with the endophytic bacteria only Healthy= Plants without any treatment or infection Infected= Plants infected with Pathogenic fungus only without bacterial treatment.

8- Effect of bio-agent application on some Pathogenesis related proteins (PR) and growth factors in both infected and un-infected sugarcane plants:

Results in Table (5) present the effect of endophytic bacteria treatments on the PO levels in the infected and un-infected sugarcane plants.

The levels of peroxidase noticed higher in infected control than in healthy control. The POlevels were significantly higher in the treated plants compared to the healthy control while the levels recorded by the treated infected plants didn't show any significant with the infected control $(0.71$ Unit/hr./g fresh wt).

The levels of PO recorded in the treated infected plants with the tested bacteria were very close.

The effect of endophytic bacteria treatments on the PPOlevels in the infected and un-infected sugarcane plants.

The data showed that, there were no noticeable effect on the levels of PPO in both treated infected plant and treated un-infected plants compared to the healthy (0.43 Unit/hr./g fresh wt) and infected control (0.51 Unit/hr./g fresh wt).

On the other hand, the effect of endophytic bacteria on chitinase activity of sugarcane treated plants Table (5).

The obtained data showed that chitinase levels dramatically increased in the treated un-infected plants compared to the healthy control. Also in the treated infected plants the levels of chitinase increased significantly than the infected control. The isolates BAN33, andBAN39 recorded the highest significant increase in chtinase $(6.12$ and $5.69 \mathrm{mg} / \mathrm{hr} /$ $\mathrm{g}$ leaf respectively) compared to the healthy and infected control.

Data in Table (5) showed that the effect of endophytic bacteria on $\beta-1,3$ glucanase was similar to chitinase. B-1, 3 glucanase levels significantly increased in the treated un-infected plants compared to the healthy control $(8.09 \mathrm{mg} / \mathrm{hr} / \mathrm{g}$ leaf $)$.

While in the treated infected plants the levels of $\beta-1,3$ glucanase increased significantly than the infected control (13.81 mg/hr/ g leaf).

Table (5): Determination of Peroxidase activity, Polyphenol-oxidase (PPO) activity, Chitinase activity and $\beta-1,3$ glucanase activity in sugarcane plants treated with smut fungus plus endophytic bacteria and / or only endophytic bacteria under artificial inoculation condition

\begin{tabular}{|c|c|c|c|c|c|c|c|c|}
\hline \multirow[t]{2}{*}{ Isolate code } & \multicolumn{2}{|c|}{$\begin{array}{c}\text { Peroxidase } \\
\text { activity } \\
\text { (Unit/hr/g fresh } \\
\end{array}$} & \multicolumn{2}{|c|}{$\begin{array}{c}\text { Polyphenol-oxidase } \\
\text { (PPO) } \\
\text { (Unit/hr/g fresh wt) }\end{array}$} & \multicolumn{2}{|c|}{$\begin{array}{c}\text { Chitinase } \\
\text { activity } \\
\text { (mg/hr/g leaf) }\end{array}$} & \multicolumn{2}{|c|}{$\begin{array}{l}\text { B-1, } 3 \text { glucanase activity (ug / hr/ } \mathrm{g} \\
\text { fresh wt.) }\end{array}$} \\
\hline & $\underline{\mathbf{F}+\mathbf{B}}$ & $\underline{\mathbf{B}}$ & $\underline{\mathbf{F}+\mathbf{B}}$ & $\underline{\mathbf{B}}$ & $\underline{\mathbf{F}+\mathbf{B}}$ & $\underline{\mathbf{B}}$ & $\underline{\mathbf{F}+\mathbf{B}}$ & $\underline{\mathbf{B}}$ \\
\hline SOH29 & 23.58 & 13.16 & 0.70 & 0.61 & 2.67 & 2.16 & 30.40 & 22.81 \\
\hline BAN39 & 20.05 & 18.00 & 0.26 & 0.00 & 5.69 & 5.00 & 15.59 & 4.61 \\
\hline BAN33 & 21.28 & 17.44 & 0.11 & 0.01 & 6.12 & 5.00 & 36.17 & 37.10 \\
\hline Q17 & 19.87 & 15.14 & 0.77 & 0.31 & 5.08 & 3.78 & 25.38 & 10.37 \\
\hline LUX27 & 17.68 & 13.55 & 0.01 & 0.01 & 5.72 & 4.87 & 33.85 & 31.10 \\
\hline LUX41 & 23.68 & 21.10 & 0.09 & 0.00 & 4.97 & 4.17 & 21.08 & 14.09 \\
\hline Healthy & \multicolumn{2}{|c|}{10.94} & \multicolumn{2}{|c|}{0.43} & \multicolumn{2}{|c|}{4.39} & \multicolumn{2}{|c|}{8.09} \\
\hline Infected & \multicolumn{2}{|c|}{14.50} & \multicolumn{2}{|c|}{0.71} & \multicolumn{2}{|c|}{4.37} & \multicolumn{2}{|c|}{13.18} \\
\hline LSD at $5 \%$ & 3.25 & 3.13 & 0.34 & 0.28 & 1.15 & 1.22 & 3.33 & 3.41 \\
\hline
\end{tabular}




\section{9- Identification of the selected active endophytic bacteria using 16S rRNA gene methods:}

Among the tested isolates six isolates from those isolates that suppressed the infection by $\mathrm{S}$. scitamineum for two successive seasons were chosen for the Identification by $16 \mathrm{~S}$ rRNA. The chosen isolates (Fig. 2) were (LUX 27 and LUX 41) representing Luxor and (BAN33 and BAN 39) representing BeniSuef, (Q17) representing Qeina, $\mathrm{SOH} 29$ representing Sohag.

The resulted Sequences of the PCR product of the $16 \mathrm{~S}$ ribosomal RNA (rRNA) gene (Fig.2) were subjected to mega blast-n searches in National center for biotechnology information, NCBI (https://blast.ncbi.nlm.nih.gov/Blast.cgi). The 6 selected endophytic bacteria isolates showed significant homologies to $16 \mathrm{~S}$ rRNA gene (partial).
The obtained 16S rRNA gene sequences of each isolate are presented in Table 6 . The similarities of $16 \mathrm{~S}$ rRNA gene sequence of the isolates were compared with the known species in GenBank, as shown in Table 6. The obtained sequencing data of $16 \mathrm{~S}$ rDNA genes grouped the selected six isolates in 6 genera, Enterobacter sp., Kosakonia sp., Klabsiella sp., Bacillus sp., Pantoea sp. and Pseudomonas sp.

The isolate the isolate LUX 27 showed 100\% similarity to Enterobacter sp. andKosakonia radicictans while LUX 41 showed $100 \%$ similarity to Kosakonia radicictans and Kosakonia oryzae; BAN 33 showed $99.88 \%$ similarity to Kosakonia radicictans and Enterobacter sp.; BAN 39 showed $100 \%$ similarity to Kosakonia radicictans and Klabsiella oxytoca.; Q17 showed $100 \%$ similarity to Bacillus subtilis subsp. inaquosorum andSOH 29 showed $99 \%$ similarity to Pantoea sp. and Pseudomonas. Agglomerans

Table (6) Identification of the selected bacteria from sugarcane by Sequence Analysis of the 16S rRNA universal bacterial primers 27F and 1492R

\begin{tabular}{|c|c|c|c|c|}
\hline No. & $\begin{array}{l}\text { Isolate } \\
\text { code }\end{array}$ & $\begin{array}{l}\text { Closest similarity of partial } 16 \mathrm{~S} \text { rRNA gene } \\
\text { sequences in the NCBI }\end{array}$ & $\begin{array}{l}\text { Accession } \\
\text { number }\end{array}$ & $\begin{array}{l}\text { Max } \\
\text { Idnt. \% }\end{array}$ \\
\hline 1 & LUX 27 & $\begin{array}{l}\text { Enterobacter sp. } \\
\text { Kosakonia radicictans }\end{array}$ & $\begin{array}{l}\text { HM748058.1 } \\
\text { MT640268.1 }\end{array}$ & 100 \\
\hline 2 & LUX41 & $\begin{array}{l}\text { Kosakonia radicictans } \\
\text { Kosakonia oryzae }\end{array}$ & $\begin{array}{l}\text { CP040392.1 } \\
\text { KJ605844.0 }\end{array}$ & 100 \\
\hline 3 & BAN 33 & $\begin{array}{l}\text { Enterobacter sp. } \\
\text { Kosakonia radicictans }\end{array}$ & $\begin{array}{l}\text { HM748058.1 } \\
\text { HM222646.1 }\end{array}$ & 99.88 \\
\hline 4 & BAN 39 & $\begin{array}{l}\text { Kosakonia radicictans, } \\
\text { Klabsiella oxytoca }\end{array}$ & $\begin{array}{l}\text { MT435030.1 } \\
\text { MK530089.1 }\end{array}$ & 100 \\
\hline 5 & Q17 & Bacillus subtilis subsp. Inaquosorum & MN931355.1 & 100 \\
\hline 6 & SOH 29 & $\begin{array}{l}\text { Pantoea sp. } \\
\text { Pseudomonas. Agglomerans }\end{array}$ & $\begin{array}{l}\text { MT367789.1 } \\
\text { HQ647279.1 }\end{array}$ & 99 \\
\hline
\end{tabular}

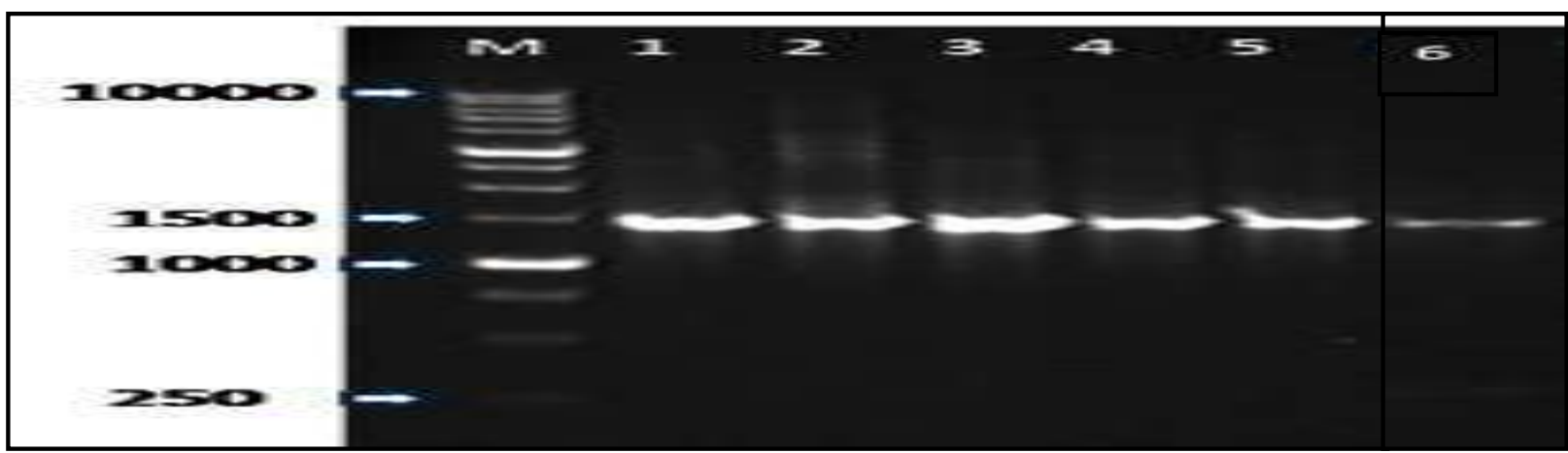

Fig. 2: Amplification 16S rDNA of the selected isolates $1=\mathrm{LUX27}, 2=\mathrm{LUX41}, 3=\mathrm{BAN39}, 4=\mathrm{BAN33}, 5=\mathrm{Q17}$ and $6=\mathrm{SOH} 29$ using the universal bacterial primers $27 \mathrm{~F}$ and $1492 \mathrm{R}$

\section{DISCUSSION}

Concerning the sugarcane endophytic bacteria, a survey was conducted during the growing seasons 2018- 2019 in the main sugarcane growing areas in Upper Egypt to isolate endophytic bacteria from sugarcane stalk tissues.

Two hundred and forty bacterial isolates were isolated from the collected 160 samples among them 6 bacterial isolates proved a bioactivity against S. scitamineum.
The term of Endophytic bacteria is indicating "the bacteria that colonize plant tissues without causing any harm or disease on host' (Yan et al., 2018 and Shastri et al., 2020).

A big list of bacterial endophytes were reported from sugarcane Chauhan et al., 2013 .The in vitro antagonistic effect of the endophytic bacteria isolated from sugarcane stems against the fungus $S$. scitamineum was studied. 
IAA is a very important auxin that is involved in different plant physiological activities. These include the cell signaling, activation of plant defense systems and controlling the plant development and growth (Gravel et al., 2007).

Shastriet al., (2020) reported that, Endophytic bacteria increase the growth level of the plant by the synthesizing a various secondary metabolites which enhance the growth of the plant in direct and indirect manner. Indole 3 acetic acid (IAA) production and phosphate solubilization are one of the important mechanisms for plant growth promotion as shown by the variety of PGP endophytes (Walitang et al., 2017 and Yan et al. 2018).

Sharma and Johri 2003 reveled that, the siderophores produced by endophytic bacteria are important to the plants because it has a role in inhibiting plant pathogens growth. The direct effect of Siderophores produced by endophytic bacteria on plant growth by supplying the plant with iron which is always exist in low concentrations, and that explains that organic chelators produced by endophytic bacteria increase iron concentration in plant and increase its growth and in the same time decreasing the iron availability to the pathogens that inhibit its growth (Szilagyi-Zecchin et al., 2014).

These siderophores produced by the endophytic bacteria capture iron form the plant pathogens and that affect the development and growth of the plant pathogens which improve the plant growth indirectly (Alexander and Zeeberi 1991).Van Loon et al., (1998) reported that, the induction of systemic resistance by plant growth promoting bacteria is related to the production of siderophore.

Among the tested bacteria only 2 isolates produced the enzyme chitinase in the medium and only 3 isolates were able to produce $\beta$-1,3-glucanase. Endophytic bacteria have received considerable attention for their potential as biocontrol agents of fungal plant pathogens. They secrete and excrete various metabolites that can interfere with the growth or activities of the pathogens. One of the most important hydrolytic enzymes that has a great role in bio-control agents is chitinases. Chitinase has been reported to be produced by many endophytic bacteria (El-Tarabily and Sivasithamparam, 2006) the two enzymes chitinase and $\beta$-1,3-glucanase together or separate have been reported to have a great role in biocontrol of plant pathogens .

All the isoletes (6) endophytic bacteria were able to produce nitrogenase, the highest significant ability in producing Nitrogenase activity BAN 39 and $\mathrm{SOH}$ 29 (1.34 nmole/ $\left.\mathrm{C}_{2} \mathrm{H}_{4} / \mathrm{ml} / \mathrm{hr}\right)$, Q17 and LUX27 (1.1 nmole $/ \mathrm{C}_{2} \mathrm{H}_{4} / \mathrm{ml} / \mathrm{hr}$ ), BAN33 then LUX 41. The endophytic bacteria fixing the nitrogen in their host plants and increase its concentration. These bacteria can provide the host with atmospheric nitrogen by activating the nitrogenase activity (Montanez et al., 2012). Nitrogen fixing bacteria like Azoarcus sp.BH72, Azospirillum brasilense, Burkholderia spp., Gluconacetobacter diazotrophics, and Herbaspirillum seropedicae found able to increase $\mathrm{N} 2$ fixation in the host and increase its biomass (Bhattacharjee et al.,2008 and Carrell and Frank, 2014).All the tested endophytic bacteria isolates were completely $100 \%$ reduced the disease incidence (symptoms expression).

The smut fungus transmitted through buds germinates along with meristem of shoots (Hoy 1993), and it was reported that entry of the fungus into bud meristem takes 6-36 $\mathrm{h}$ after teliospore deposition (Alexander and Ramakrishnan 1980). Jayakumar et al., (2019) reported that, sugarcane setts pre-treated with endophytic bacteria showed a higher percentage of germination than the untreated.

Natural products from endophytic microbes have been observed to inhibit or kill a wide variety of harmful disease-causing agents including, phytopathogens. A number of mechanisms are leading to these antagonistic activities, such as pathogen growth inhibition through antibiotics, toxins and degrading enzymes such as proteases, cellulases and chitinases (de Souza et al., 2003). Uroz et al., 2003 and Newton and Fray 2004 reported that certain plant growth promoting bacteria interfere pathogen quorumsensing signals, and blocking the expression virulence genes.

On the other hand the sugarcane plants treatment with different endophytic bacteria led to a significant increase in some of the studied plant characteristics (leaf area, stalk height, stalk diameter, number of tillers and the total chlorophyll).

Some of the endophytic bacteria treatment caused a significant increase in the determined plant characteristics either in the infected or un-infected plant compared to the un-treated plants or infected control respectively. IsolatesSOH29, BAN33, LUX41, Q17 and LUX27 it was noticed that the IAA level produced by these isolates was high as well as the total chlorophyll. That might be the reason of increasing leaf area. These results are in agreement with work of Ma et al., (2016) and Shastri et al., (2020) on the direct effects of endophytic bacteria on assisting plants in getting nutrients, and improving its growth by producing plant growth substances, which can help plants to grow better under normal and stressed conditions.

The auxins functions are cell division, extension, and also the differentiation of plant cells and tissues. Plant growth regulators belongs to this group activate the germination of seed and tuber; control plant growth, and fructification of plants; and also affect photosynthesis, pigment formation, biosynthesis of various metabolites, and resistance to stress factors.

IAA exhibits the greatest activity, although plants are known to contain other auxins, most of them also belonging to indole derivatives (structurally similar to IAA). These indoles may be precursors or products of the transformation of IAA (Tsavkelova et al., 2006).

From the present work, it was found that, the peroxidase and polyphenol oxidase levels significantly increased in infected sugarcane plants treated with the endophytic bacteria isolates and also 
in the treated uninfected sugarcane plants. On the other hand, it was noticed that the enzyme levels were higher in the treated infected plants than in the treated un infected plant.

The activity of peroxidase in sugarcane plants is significantly increased after smut infection, and the enzyme activity of resistant varieties is higher than that of susceptible varieties (Esh et al., 2014 and Xiupeng et al., 2019). Karthikeyan et al., 2005 reported that, the black gram plants treated with endophytic bacteria showed increased activities of peroxidase (PO), polyphenol oxidase (PPO) in addition to accumulation of phenolics and lignin after inoculation with the causal pathogen of dry root rot. On the other hand it was found that, the endophytic bacteria Serratia marcescens, activated the production of peroxidase, polyphenol oxidase, phenylalanine and ammonia lyase, as well as the total soluble phenols and lignothioglycolic acid in banana (Singh et al., 2017).

Polyphenol oxidase is responsible of the oxidation of phenols to form strontium and the polymerization of lignin. Several experiments suggested that poly-phenol oxidase activity is a marker for plant disease resistance (Xiupeng et al., 2019).

Esh et al., 2014 reported that the levels of phenylalanine ammonia lyase, peroxidase, polyphenol oxidase, chitinase and $\beta$-1,3-glucanase increased dramatically in the resistant smut infected sugarcane plants compared to the susceptible infected plants and to the control. Xiupeng et al., 2019 reported that, in smut resistant sugarcane varieties it was noticed that the activity of chitinase, $\beta$-1, 3-glucanase, peroxidase and polyphenole oxidase increased after inoculation. Chitinase belong to PR families 3, 4, 8, and 11 and have been characterized in tobacco Legrand, et al., (1987), sugarcane Esh et al., (2014) and sugar beet Bargabus et al., (2002). Plant growth-promoting bacteria (PGBR) can affect plant growth in both ways directly or indirectly. The direct effect of PGBR on plant growth include helping the plant to use macro and micro nutrients and also regulating plant growth by producing different growth regulators such as auxin, cytokinin or ethylene. Indirect effect of plant growth by PGBR is that the bacterium limits or prevents diseases caused by various pathogenic agents such as bacteria, fungi and nematodes. The indirect effects of PGBR include the production of antibiotics, cell wall-degrading enzymes, lowering plant ethylene levels, induced systemic resistance, capturing the iron from the pathogen and the producing of volatile compounds that inhibit the hyphal growth (Glick, 2015).

In order to identify the bioactive bacterial isolates namely (LUX 27, SOH 29, LUX41, Q17, BAN 39, BAN 33) were subjected to DNA sequence analysis. The obtained sequencing data of 16S rRNA genes grouped the selected six bioactive isolates in 6 genera, Enterobacter sp., Kosakonia sp., Klabsiella sp., Bacillus sp., Pantoea sp. and Pseudomonas sp.
The isolate ( $\mathrm{SOH} 29)$ was identified as Pantoaesp. recently, based on total DNA homology and electrophoretic protein pattern similarities, some strains of E. agglomerans and E. herbicola, including the two type strains were proposed to form a new genus called Pantoea (Gavini et al. 1989).Found endophytically in sugarcane many important crops, acting as a plant growth promoter (Quecine et al., 2012), bio-control agent (Plaza et al., 2004), and even a systemic resistance inducer (Liu et al., 1995).

The isolate (LUX27, BAN33) was identified as Kosakonia was classified as a member of Enterobacter and but now it is separated to be new genus (Brady et al., 2013). After that, a strain of endophytic diazotrophic bacteria isolated from sugarcane plants was described as Kosakonia sacchari (Chen et al., 2014) while other members of the genus Kosakonia are beneficially associated with cereal crops. K. radicincitans was isolated from wheat and it increase the growth of other plants, such as shorting the time of the flowering and ripening of tomato (Berger et al., 2017). Kleingesinds et al., 2018 reported that, Kosakonia sp. ICB117 able to produce IAA in vitro, and increase sugarcane root dry mass. Kosakonia sacchari found associated with sugarcane (Saccharum officinarum) (Chen et al., 2014).Kim et al., 2011 and Orberáet al., 2014 reported that, B. subtilis subsp. inaquosorum could be used as a biological control agent. The bacterium was able to inhibit the liner-growth of different pathogenic fungi in vitro such as Fusarium oxysporum and Fusarium solani as well as members of the Colletotrichum sp.

The isolate (Q17) was identified as Bacillus subtilis produces Iturins which is a group of antifungal compounds known as iturinic lipopeptides. The Iturins group consists of different compounds namelly: iturin, bacillomycin $\mathrm{D}$, bacillomycin $\mathrm{F}$, bacillomycin L, mycosubtilin, and mojavensin. These compounds are produced by many Bacillus strains used in commercial bio-fungicides against fungal plant pathogens and as plant growth promoters (Dunlap et al., 2019).

Bacillus.subtilissubsp. inaquosorum is the only one reported to produce bacillomycin $\mathrm{F}$, while, $\mathrm{B}$. velezensis found the only species to produce bacillomycin L. it was reported that, B. velezensis also produces bacillomycin D instead of bacillomycin L. (Dunlap et al., 2019). Kim et al., 2011 and Orberá et al., 2014 reported that, B. subtilis subsp. inaquosorum could be used as a biological control agent.

The bacterium was able to inhibit the liner-growth of different pathogenic fungi in vitro such as Fusarium oxysporum and Fusarium solani as well as members of the Colletotrichum sp. They suggested that the bacterium secreting different antifungal compounds that responsible for this inhibition.

This would explain the high bio-control activity of this isolate against sugarcane smut fungus in the in vitro and the in vivo studies. 
The isolate (LUX41, BAN33 and BAN39) were identified as Kosakonia sp.

The genus Kosakonia was classified as a member of Enterobacter and but now it is separated to be new genus (Brady et al., 2013).

\section{REFERENCES}

Adeniji, A. A., and Babalola, O.O. 2019. Bacillus velezensis: phylogeny, useful applications, and avenues for exploitation. Appl. Microbiol. Biotechnol. Doi: 103:3669-3682.

Alexander, B. D., and Zeeberi, D. A. 1991. Use of chromazurol $\mathrm{S}$ to evaluate siderophore production by rhizosphere bacteria. Biol Fertil Soils. 2:39-54.

Alexander, K. C., and Ramakrishnan, K. 1980.Infection of the bud, establishment in the host and production of whips in sugarcane smut (Ustilago scitaminea) of sugarcane. Proceedings of the International Society of Sugarcane Technology, 17:1452-1455.

Araujo, W. L., Maccheroni, W. Jr., Aguilar-Vildoso, C. I., Barroso, P. A., Saridakis, H. O., and Azevedo, J. L. (2001). Variability and interactions between endophytic bacteria and fungi isolated from leaf tissues of citrus rootstocks. Can. J. Microbiol. 47: 229-236.

Asis C. A. Jr., and Adachi, K. (2003). Isolation of endophytic diazotroph P. agglomerans and nondiazotroph Enterobacter asburiae from sweet potato stem in Japan. Letters in Applied Microbiology. 38: 19-23.

Benhamou, N., Kloepper, J.W., and Tuzun, S., (2000). Induction of resistance against Fusarium wilt of tomato by combination of chitosan with an endophytic bacterial strain: ultrastructure and cytochemistry of the host response. Planta. 204: 153-168.

Berg, G., Kurze, S., Buchner, A. E., Wellington, M., and Smalla, K. 2000. Successful strategy for the selection of new strawberry-associated rhizobacteria antagonistic to Verticillium wilt.Can. J .Microbiol. 46: 1128-1137.

Berger B, Baldermanna, S., and Ruppel, S. 2017. The plant growth promoting bacterium Kosakonia radicincitans improves fruit yield and quality of Solanum lycopersicum. J. Sci. Food. Agric. 1-7.

Berger, L. R., and Reynolds, D. M. 1958.The chitinase system of a isolate of Streptomyces griseus. Biochem .Biophys. Acta. 29: 522-534.

Bhattacharjee, R. B., Singh, A., and Mukhopadhyay, S. N. 2008. Use of nitrogenfixing bacteria as biofertiliser for non-legumes: prospects and challenges. Appl. Microbiol. Biotechnol. 80: 199-209.

Boddey, R. M., Urquiaga, S., Reis, V., Dobereiner, J. 1991. Biological nitrogen fixation associated with sugar cane. Plant Soil. 137: 111-117.
After that, a strain of endophytic diazotrophic bacteria isolated from sugarcane plants was described as Kosakonia sacchari (Chen et al., 2014) .Reported that, Kosakonia sp. ICB117 able to produce IAA in vitro, and increase sugarcane root dry mass.

Kosakonia sacchari found associated with sugarcane (Saccharum officinarum) (Chen et al., 2014).

Bollag, D. M., Edelstein, S. J., Rozycki, M. D. 1996. Protein methods.New York (N.Y.): WileyLiss.XVI. 415p.

Brady, C., Cleenwerckb, I., Venterc, S. Coutinhoc, T., and De Vos, P. 2013. Taxonomic evaluation of the genus Enterobacter based on multilocus sequence analysis (MLSA): Syst. Appl. Microbiol. 36: 309-319.

Bricet, J. M., Bostock, R. M., and Silverstone, S. E. 1991. Rapid in situ assay for indol acetic acid production by bacteria immobilized on aitrocellulose membrane. Appl. Eniron. Microbiol. 57: 535-538.

Cao, Y. H. Pi., Chandrangsu, P., Li, Y., Wang, Y., and Zhou, H. 2018. Antagonism of two plantgrowth promoting Bacillus velezensis isolates against Ralstonia solanacearum and Fusarium oxysporum. Sci. Rep. 8: 4360. doi: 10.1038/s41598-018-22782-z.

Carrell, A. A., and Frank, A. C. 2014. Pinus flexilis and Picea engelmannii share a simple and consistent needle endophyte microbiota with a potential role in nitrogen fixation Frontiers in Microbiology. 5: 333

Chauhan, H., Bagyaraj, D., and Sharma, A. 2013. Plant growth promoting bacterial endophytes from sugarcane and their potential in promoting growth of the host under field conditions. Experimental Agriculture. 49: 43-52.

Chen, M., Zhu, B., Lin, L., Yang, L., Li, Y., and An, Q. 2014. Complete genome sequence of Kosakonia sacchari type strain SP1. Stand Genomic Sci. 9: 1311-1318.

Comstock,J.C. and Heinz, D.J. 1977. Anew race of culmicolous smut of sugarcane in Hawaii.Sugarcane Pathologists Newsletter. 19: 24-25.

Demain, A. L. 1981. Industrial microbiology. Sci Am. 24: 67-75.

Dilowrth, M. J. 1966. Acetylene Reduction by nitrogen -fixing preparations from clostridium pasteurianum. Biochim Biophys Acta. 127: 28594.

Dunlap, C. A., Kim, S. J., Kwon, S. W., and Rooney, A. P. 2019. Bacillus velezensis is not a later heterotypic synonym of Bacillus amyloliquefaciens; Bacillus methylotrophicus, Bacillus amyloliquefaciens subsp. plantarum and 'Bacillus oryzicola' are later heterotypic synonyms of Bacillus velezensis based on phylogenomics. Int. J. Syst. Evol. Microbiol. 66: 1212-1217. 
El-Tarabily, K. A., and Sivasithamparam, K. 2006. Non-streptomycete actinomycetes as biocontrol agents of soil-borne fungal plant pathogens and as plant growth promoters. Soil Biol. Biochem. 38: 1505-1520.

Esh, A. M. H., Guirgis, A. A., El-kholi, M. M. A., El Absawy, E.A., Nasr, M. I. Hassanien, E.H. 2014. The activity of pathogenesis related proteins in smut resistant and susceptible sugarcane (GT549) mutants induced by gamma radiation. Adv. Plants. Agric. Res. 1: 146-156.

Gavini, F. J., Beji, M., Mielcarek, A. C., Izard, D., Kerster, K., and De Ley, J. 1989. Transfer of Enterobacter agglomerans (Beijerink 1988) Ewing and File 1972 to Pantoea gen. nov. asPantoea agglomerans comb. nov. and description of Pantoea dispersa sp. nov. Int. J. Syst. Bacteriol. 39: 337-345.

GillaspieA. G., Mock, R. G., and Dean, J. L. 1983. Differentiation of Ustilago scitaminea isolates in greenhouse. Plant Dis. 67: 373-375.

Glick B.R. 2015. Plant growth-promoting bacteria: mechanisms and applications Plant GrowthPromoting Bacteria: Mechanisms and Applications Hindawi Publishing Corporation, Scientifica. : 12.

Gravel, V., Antoun, H. and Tweddell, R. J. 2007. Growth stimulation and fruit yield improvement of greenhouse tomato plants by inoculation with Pseudomonas putida or Trichoderma atroviride: possible role of indole acetic acid (IAA). Soil Biol. Biochem. 39: 1968-1977.

Hartmann A. and Baldani J.I. 2006. The genus Azospirillum // The Prokaryotes, V. 5: Proteobacteria Alpha and Beta Subclasses // Eds. M. Dworkin, S. Falkow, E. Rosenberg, K.H. Schleifer, E. Stackebrandt. - Springer Verlag, New York, USA. :115-140.

Hinton, D.M., and Bacon, C.W. 1995. Enterobacter cloacae is an endophytic symbiont of corn. Mycopathologia 129: 117- 125.

Hoy, J. W. 1993. Sugarcane smut in Louisiana: Biology and control. Louisiana Agricultural Experiment Station Bulletin, 31. USA.

Jayakumar, V., Sundar, A. Ramesh., and Viswanathan, R. 2019. Biological Suppression of Sugarcane Smut with Endophytic Bacteria. Sugar Tech. 21: 653-660.

Jones, G. H. 1935. Egyptian plant diseases; summary of research and control methods. Tech. Bull. Minis of Agric. 146.

Kar, M. and Mishra, D. 1976. Catalase, Peroxidase, and polyphenol oxidase activities during rice leaf senescence. Plant Physiol. 57: 315-319.

Karthikeyan, M., Bhaskaran, R., Radhika, K., Mathiyazhagan, S., Jayakumar V., and Sandosskumar R. $2005 . \quad$ Entophytic seudomonas fluorescens Endo2 and Endo35 induce resistance in black gram (Vigna mungo L. Hepper) to the pathogen Macrophomina phaseolina. J. Plant Interact. 1: 135-143.

Keyeo, F., Noor, O., and Amir, H. G. 2011. The effects of nitrogen fixation activity and phytohormone production of diazotroph in promoting growth of rice seedling. Biotechnology. 10: 267-273

Kim, Y. C, Leveau, J., McSpadden Gardener, B. B., Pierson Pierson, E. A., L.S, 3rd., Ryu, C. M. 2011. The multifactorial basis for plant health promotion by plant-associated bacteria. Appl Environ Microbiol. 77(5): 1548-55.

King J.V., Campbell, J.R., Eagles, B.A. 1948. The mineral requirments for fluorescin production.Candian Journal of Research. 26: 514-519.

Kleingesinds, C. K., de Santi Ferrara1, F. I., Floh, E. I. S., Aidar, M. P. M., and Barbosa, H. R. 2018. Sugarcane growth promotion by Kosakonia sp. ICB117 an endophytic and diazotrophic bacterium. Afr. J. Microbiol. Res. 12: 105-114.

Kucuk, C., and Kivanc, M. 2003. Isolation of Trichoderma spp. and determination of their antifungal, biochemical and physiological features. Turkish Journal of Biology, 27, 247-253.

Legrand, M., S. Kauffmann, P. Geoffroy, B. Fritig, (1987) Biological function of pathogenesisrelated proteins: four tobacco pathogenesisrelated proteins are chitinases. Proc. Natl. Acad. Sci. USA. 84: 6750-6754.

Lim, H., Kim, Y., and Kim, S. 1991. Pseudomonas stutzeriYLP-I genetic transformation and antifungal mechanism against Fusariumsolani, an agent of plant root rot .Appl. Environ. Microbiol. 57: 510-516.

Liu L., Kloepper, J.W., and Tuzun, S. 1995. Induction of systemic resistance in cucumber against Fusarium wilt by plant growth-promoting rhizobacteria. Phytopathology. 85: 695-698.

Liu, B., Ge, B., Azhar, N., Zhao, W., Cui, H., and Zhang, K. 2018. Complete genome sequence of Bacillus methylotrophicus strain NKG-1, isolated from the Changbai Mountains, China. Genome Announc. 6: e01454-17. doi: 10.1128/genomeA.01454-17.

Liu, S., Lin, N., Chen, Y., Liang, Z., Liao, L., Lv, M., Chen, Y., Tang, Y., He, F., Chen, S., Zhou, J., and Zhang, L. 2017. Biocontrol of Sugarcane Smut Disease by Interference of Fungal Sexual Mating and Hyphal Growth Using a Bacterial Isolate. Front. Microbiol. 8: 778.

M'Piga, P., Belanger, R. R., Paulitz, T. C., Benhamou, N. 1997. Increased resistance to Fusarium oxysporum f. sp. radicis-lycopersici in tomato plants treated with the endophytic bacterium Pseudomonas fluorescens strain 63-28. Physiol. Mol. Plant. Pathol. 50: 301-332

Ma Y., Rajkumar, M., Zhang, C., Freitas, H. 2016. Beneficial role of bacterial endophytes in heavy metal phytoremediation J. Environ.Manage. 174: $14-25$. 
Malik, C. P., and Singh, M. B. 1990. Extraction and estimation of amino acids and kito acids. In: Plant Enzymology and histo-Enzymology. New DelhiLud Hana, India.

Matta, A., and Dimond, A. E. 1963. Symptoms of fusarium wilt in relation to quantity of fungus and enzyme activity of tomato stems. Phytopathology. 53: $574-578$

McInroy, J. A., and Kloepper, J. W. 1995. Survey of indigenous bacterial endophytes from cotton and sweet corn. Plant Soil. 173: 337-342.

https://www.researchgate.net/profile/Samina_ Mehnaz?_sg\%5B0\%5D=4Zy7NtHn000bFiOM sOFjbjDPrjzQRUF--9-IfYmiXIBCS4-

DpVbVjAjUrj2u23tIEVSSvC8.vaxstVWkclJkeU qXgSoIWOCf8DWYgjbufK-

xFEXjY08EQQfvY02avili1_9LaqvP36VZwHTG ASK-2jR-

Ta6 Sw\& sg\%5B1\%5D=vtppjzfcMmMs1z6i6 VXTPdr9uzw8jGiOSYm1VcwPFzbq8VDdydj3g QW23EVXov0MqiYJ3eQ.tdK62dGyGm4h6Ct uaF74WrvHelAKxUQAtvZolhRfKrO88ihkYLee 2_FbQ1MWZnolN1IQ69JpDhNzXcZ0iVcbRQ Mehnaz, S., Weselowski, B., and Aftab, F. 2009. Isolation, characterization and effect of fluorescent pseudomonads on micropropagated sugarcane.canadian journal of Microbiology. 55(8): 1007-11.

Mendes, R.A.A., Pizzirani-Kleiner., Araujo, W.L., and Raaijmakers, J.M. 2007. Diversity of Cultivated Endophytic Bacteria from Sugarcane: Genetic and Biochemical Characterization of Burkholderia cepacia Complex Isolates. Applied and Environmental Microbiology. 73: 72597267.

Meyer, J.M.P., Zealander, A., and Georges, C. 1992. Iron metabolism in Pseudomonas: salicylic acid, a siderophore of Pseudomonasfluorescens CHAO. Biofactors. 4: 23-27.

Mirza S. M., Ahmad, W., and Latif, F. 2001. Isolation, partial characterization, and the effect of plant growth-promoting bacteria (PGPB) on micro-propagated sugarcane in vitro. Plant Soil. 237: 47-54.

Morgulis, A., Coulouris, G., Raytselis, Y., Madden, T. L., Agarwala, R., and Schäffer, A. A. 2008. Database Indexing for Production Mega BLAST Searches, Bioinformatics. 24: 1757-1764.

Moutia J. F.Y., Saumtally, S., Spaepen, S., Vanderleyden, J. 2010. Plant growth promotion by Azospirillum sp. in sugarcane is influenced by genotype and drought stress. Plant and Soil. 337: 233-242.

Naguib, M. I. 1965. Effect of maleic hydrazine on the nitrogen metabolismduring the germination of cotton seed. Ind. J. Exp. Biol. 2: 149-152.

Nelson, N. 1944. A photometric adaptation of the Somogy method for the determination of glucose. J. Biol. Chem. 152: 375-380.
Newton, J. A., and Fray, R. G. 2004. Integration of environmental and host-derived signals with quorum sensing during plant-microbe interactions.Cell. Microbiol. 6: 213-224.

Orberá T. M., Serrat, M., Ortega, E. 2014. Potential applications of Bacillus subtilis strain SR/B-16 for the control of phytopathogenic fungi in economically relevant crops. Biotecnol Apl. 31: 13-17.

Piepenbring, M., Stoll, M., and Oberwinkler, F. 2002. The generic position of Ustilago maydis, Ustilago scitaminea, and Ustilago esculenta (Ustilaginales). Mycological Progress. 1: 71-80.

Pinto, C., Sousa, S., Froufe, H., Egas, C., Clément, C. and Fontaine, F. 2018. Draft genome sequence of Bacillus amyloliquefaciens subsp. plantarum strain Fito_F321, an endophyte microorganism from Vitis vinifera with biocontrol potential. Stand. Genomic Sci. 13:30.

Plaza P., Usall, J., Smilanick, J. L., Lamarca, N. Vinas, I. 2004. Combining Pantoea agglomerans (CPA-2) and curing treatments to control established infections of Penicillium digitatum on lemons J. Food Prot. 67: 781- 786.

Quecine, M. C., Araújo, W. L., Rossetto, P. B., Ferreira, A., Tsui, S., Lacava, P. T., M. Mondin, J., Azevedo, L., and Pizzirani-Kleiner, A. A. 2012. Sugarcane Growth Promotion by the Endophytic Bacterium Pantoea agglomerans 33.1. Applied and Environmental Microbiology. 78: 7511-7518.

Queiroz, M.V., de Oliveira Costa, L. E., Borges, A.C., de Moraes, C.A., de Araújo, E.F. 2012. Isolation and characterization of endophytic bacteria isolated from the leaves of the common bean (Phaseolus vulgaris). Braz J Microbiol. 43(4): 1562-1575.

Rabbee, M.F., Ali, M. J., Choi, B.S., HwangJeong, S.C., and Baek, K. H. 2019. Bacillus velezensis: a valuable member of bioactive molecules within plant microbiomes. Molecules. 24: E1046.

Ramamoorthy, V., Raguchander, T., and Samiyappan, R. 2002. Induction of defenserelated proteins in tomato roots treated with Pseudomonas fluorescens Pf1 and Fusarium oxysporum f. sp. lycopersici. Plant Soil. 239: 5568.

Reeves, M., Pine, L., Neilands, J. B., and Bullows, A. 1983. Absence of siderophore activity in Legionella spp. grown in iron deficient media. J. Bacteriol. 154: 324-329.

Reinhold-Hurek, B., and Hurek, T. 1998. Life in grasses: Diazotrophic endophytes. Trends Microbiol. 6: 139-144.

Reissig, J. L., Stringer, J. L., and Leloir, L. F. 1955. A modified colorimetric method for the estimation of $\mathrm{N}$-acetylaminosugars.J. Biol. Chem. 217: 959-966.

Rennie R. J., Freitas, J. R., Ruschel, A. P., Vose, P. B. 1982. Isolation and identification of N2-fixing bacteria associated with sugar cane (Saccharum sp.). Can J Microbiol. 28: 462-467. 
Rosenblueth, M., and Martínez-Romero, E. 2006. Bacterial endophytes and their interactions with hosts. Mol. Plant Microbe Interact. 19: 827-837.

Ruiz-García, C., Bejar, V., Martinez-Checa, F., Llamas, I., and Quesada, E. 2005. Bacillus velezensis sp. nov., a surfactant-producing bacterium isolated from the river Velez in Malaga, southern Spain. Int. J. Syst. Evol. Microbiol. 55: 191-195.

Ruppel, S., Heck-Buchholz, C., Remus, R., Ortmann, U., and Schmelzer, R. 1992. Settlement of the diazotrophic, phytoeffective bacterial strain $\mathrm{P}$. agglomerans on and within winter wheat: an investigation using ELISA and transmission electron microscopy. Plant and Soil. 145: 261-273.

Santhanam, R., Groten, K., Meldau, D. G. and Baldwin, I. T. 2014. Analysis of plant-bacteria interactions in their native habitat: bacterial communities associated with wild tobacco are independent of endogenous jasmonic acid levels and developmental stages.PLoS One. 9: 94710.

Santoyo, G., Moreno-Hagelsieb, G., del Carmen OrozcoMosqueda, M., and Glick, B. R. 2016. Plant growth-promoting bacterial endophytes. Microbiological Research. 183: 92-99.

Scholz-Seidel, C., and Ruppel, S. 1992. Nitrogenaseand phytohormone activities of $\mathrm{P}$. agglomerans in culture and their reflection in combination with wheat plants.Zentralblatt für Mikrobiologie. 147: 319-328.

Sharma, A., and Johri, B. N. 2003. Growth promoting influence of siderophore-producing Pseudomonas strains GRP3A and PRS9 in maize (Zea mays L.) under iron limiting conditions. Microbiol Res. 158:243-8.

Shastri, B., Kumar, R., and Lal, R. J. 2020. Isolation, Characterization and Identification of Indigenous Endophytic Bacteria Exhibiting PGP and Antifungal Traits from the Internal Tissue of Sugarcane Crop. Sugar Tech. 22: 563-573.

Shinjo, R., Uesaka, K., Ihara, K., Loshakova, K., Mizuno, Y., Yano, K., Tanaka, A. 2016. Complete genome sequence of Kosakonia sacchari strain BO-1, an endophytic diazotroph isolated from a sweet potato. Genome Announcements. 4.4 doi: 10.1128/genomeA.00868-16.

Singh, M., Kumar, A., Singh, R., and Deo Pandey, K. 2017. Endophytic bacteria: a new source of bioactive compounds.3 Biotech. 7: 315.

Soltis D. Pamela, E., Soltis, S. 1990. Isozymes in plant biology. London: Chapman and Hall Ltd.

Szilagyi-Zecchin V. J., Ikeda, A. C., Hungria, M., Adamoski, D., Kava-Cordeiro, V., Glienke, C., Galli-Terasawa, L. V. 2014. Identification and characterization of endophytic bacteria from corn (Zea mays L.) roots with biotechnological potential in agriculture. AMB Express.: 4-26.

Taghavi, S., van der, L. D., Hoffman, A., Zhang, Y.B., Walla, M. D., Vangronsveld, J., .Newman, L., Monchy,S. 2010. Genome sequence of the plant growth promoting endophytic bacterium Enterobacter sp. 638. PLoS Genet. 6: e1000943.

Talboys, P. J., Owen, D. W., Healey, J. R., Withers, P. J., and Jones, D. L. 2014. Auxin secretion by Bacillus amyloliquefaciens FZB42 both stimulates root exudation and limits phosphorus uptake in Triticum aestivum. BMC Plant Biol. 14: 51.

Tsavkelova E. A., Klimova, S. Yu., Cherdyntseva, T. A., and Netrusov, A. I. 2006. Microbial Producers of Plant Growth Stimulators and Their Practical Use: A Review Applied Biochemistry and Microbiology. 42: 117-126.

Uroz, S., D'Angelo-Picard, C., Carlier, A., Elasri, M., Sicot, C., Petit, A., Oger, P., Faure, D., and Dessaux, Y. 2003. Novel bacteria degrading Nacylhomoserine lactones and their use as quenchers of quorum-sensing-regulated functions of plant-pathogenic bacteria. Microbiology. 149: 1981-1989.

Van Loon, L. C., P. Bakker, A. H. M., and Pieterse, C. M. J. 1998. Systemic resistance induced by rhizosphere bacteria. Annu Rev Phytopathol. 36: 453-483.

Verma S. C., Singh, A. S., Chowdhury, P. Tripathi, A. K. 2004. Endophytic colonization ability of two deep-water rice endophytes, Pantoea sp. and Ochrobactrum sp., using green fluorescent protein reporter. Biotech. Letters. 26: 425-429.

Viswanathan R., Rajitha, R., Ramesh Sundar A., and Ramamoorthy V. 2003. Isolation and Identification of Endophytic Bacterial Strains from Sugarcane Stalks and Their In Vitro Antagonism against the Red Rot Pathogen. Sugar tech. 5: 25-29.

Walitang, D. I., Kim, K., Madhaiyan, M., Kim, Y. K., Kang, Y., and Sa, T. 2017. Characterizing endophytic competence and plant growth promotion of bacterial endophytes inhabiting the seed endosphere of Rice. BMC Microbiology. 17: 209.

Xiupeng S., Fenglian, M., Krishan, K. V., Jinju, W., Xiaoqiu, Z., Litao Y., and Yang, R .L. 2019. Effect of Sugarcane Smut (Ustilago scitaminea Syd.) on Ultrastructure and Biochemical Indices of Sugarcane. Biomed J Sci \& Tech Res. 17: 12546-12550.

Xu, T., Zhu, T., and Li, S., 2016. $\beta$-1,3-1,4-glucanase gene from Bacillus velezensis ZJ20 exerts antifungal effect on plant pathogenic fungi. World J. Microbiol.Biotechnol. 32: 26.

Yan, X., Wang, Z., Mei, Y., Wang, L., Wang, X., Xu, Q., Peng, S., Zhou, Y., and Wei, C. 2018. Isolation, diversity, and growth-promoting activities of endophytic bacteria from tea cultivars of Zijuan and Yunkang-10. Frontiers in Microbiology. 9: 1848.

Zhang, X. G., Luo, W. F., Yang, Y. L., Zhang, S. G., and Zhang, T.Y. 2000. Genetic relationships of Phytophthora parasiticavar. nicotianae analyzed by RAPD.Mycosystema. 19: 39-44. 


$$
\text { الملخص العربي }
$$

البكتريا الداخليه ودورها في المقاومه الحيويه لمرض التفحم فى قصب السكر وتاثيرها على خصائص النمو للنباتات

شاديه تغيان' - أيمن محم حسنى عش' +ـ ناجى يس عبد الغفار 'ـ عفاف زين العابدين المنيسى'

ا. مركز البحوث النزراعيةـ معهب البحوث المحاصيل السكرية ـ قسم بحوث امراض المحاصيل السكرية ـ الجبيزة - مصر.

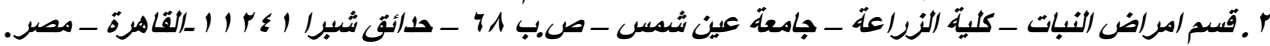

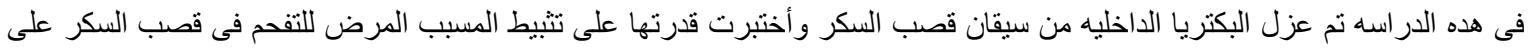

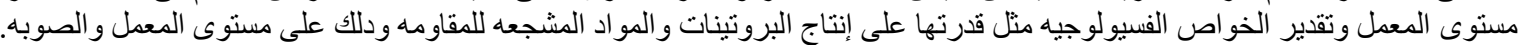

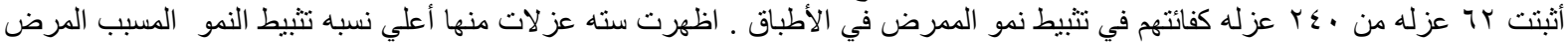

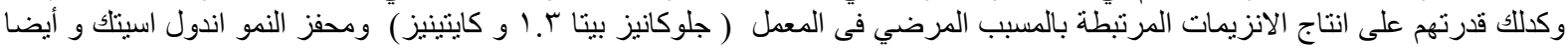

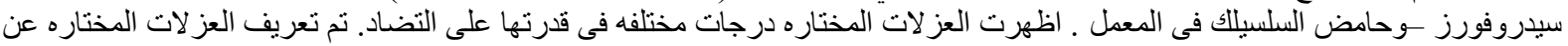
طريق تتابعات الحامض النووي اسط اس رنا الر ابوسومي وكانت نتيجه التعريف هى:

Enterobacter sp.( LUX 27), Kosakonia radicictans (LUX41), Kosakonia radicictans(BAN 33), Klabsiella oxytoca (BAN 39), Bacillus subtilis subsp. Inaquosorum(Q17), Pantoea sp.(SOH 29).

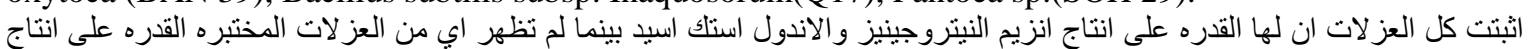

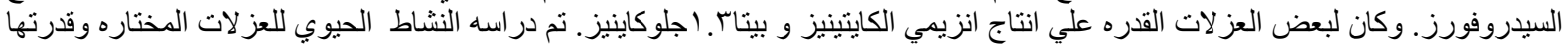

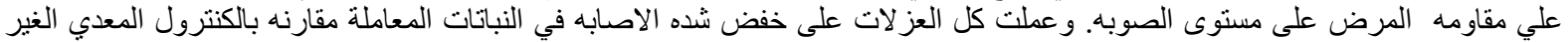

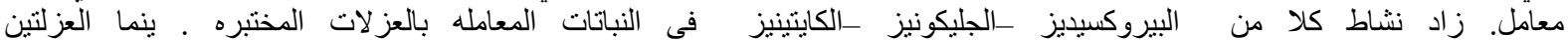
sp.Enterobacter radicictansKosakonia

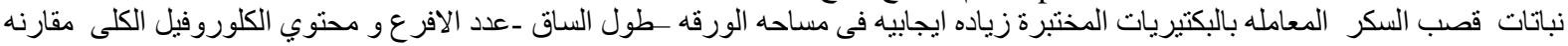

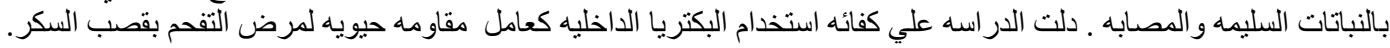

الكلمات الداله: البكتريا الد/خليه -التضاد -الكيتينيز - بيتا م. 1 جلوكاينيز - سيلروفورز - حامض اندول اسيتك - حامض سلسيلك. 